\title{
Assessment of Waste Management Practice in Health Institution: A Case Study of University College Hospital Ibadan, Nigeria
}

\author{
${ }^{1}$ ODUNOLA, Olutayo Olaitan*, ${ }^{2}$ MORENIKEJI Timothy Oluseye, ${ }^{3}$ ODUNSI Oluwafemi Michael. \\ ${ }^{1}$ Department of Urban and Regional Planning, Ladoke Akintola University of Technology, Ogbomoso, NIGERIA. \\ ${ }^{2}$ Department of Urban and Regional Planning, University of Ibadan, NIGERIA. \\ ${ }^{3}$ Department of Urban and Regional Planning, Obafemi Awolowo University, Ile-Ife, NIGERIA.
}

\begin{abstract}
Efficient management of medical waste is a necessity because of great risk improper/poor waste management posed to the populace. This study assessed medical waste management practice in University College Hospital Ibadan, Nigeria. Those that improper waste management can affect are identified as the sample frame, and they are health workers, waste handlers, out-patients and residents. Sample size of 5\% of the 3000 staff strength of the study area was adopted which amounted to one hundred and fifty (150) respondents. A multistage sampling technique was adopted in the sample selection and the administration of the questionnaires until all copies of questionnaire assigned for each category of respondents were administered. Nine indices were developed, these were: Waste Collection Index (WCI), Waste Storing Index (WSI), Waste Treatment Index (WTI), Facility Condition Index (FCI), Medical Waste Index (MWI), Storage Factor Index (SFI), Waste Effect Index (WEI), Waste Preventive Index (WPI) and Health Workers Satisfactory Index (HSI).The study observed that punctured proof container has WCI of 4.49; lidded container has the highest WSI of 4.56, while compositing and landfill has the highest WTI of 3.67. Gloves and head cap have the highest and lowest FCI with 4.40 and 1.00 respectively. Infectious waste is the major generated waste in the study with MWI of 4.46 and offensive odour with highest WEI of 3.77 while good accessibility has the highest SFI of 4.53. A major preventive measure as perceived the respondents is enforcement of regulation with WPI of 4.16 while workers' welfare has the highest HSI of 3.57.For proper medical waste management practice, therefore, there should be an incentive package for health workers and adequate fund should be provided to carry out this proper management from on-site to off-site disposal. Time-to-time training for waste handlers in order to keep them abreast of the recent risk involved or update about medical waste and waste management policy should be re-assessed and reviewed where necessary so as to keep it up-to date.
\end{abstract}

Keywords:- Health Regulations, Healthcare Institutions, Health Workers, Medical Waste Index, Waste Facilities.

\section{INTRODUCTION}

Health institution is in place to ensure provision of safe, quality, affordable, adequate, equitable and accessible health services to all people [1]. International community recognize the critical importance of this sector and the need to strengthen health systems as a whole to the achievement of major global health goals [2], Despite its importance, the waste being generated from it poses great threat to the environment which is otherwise known as special or regulated medical waste [3].

Any waste generated in the diagnosis, treatment, or immunization of human beings or animals, in related research, production or testing of biological from all types of healthcare institutions, including hospitals, clinics, doctor (dental and veterinary) offices, and medical laboratories is known as medical waste [4]. Medical wastes primarily consist of pathological, infectious, chemical, pharmaceutical, and domestic wastes as well as sharps that have been contaminated with blood, infectious agents, tissues, organs, etc [5].

Medical waste and its management are of great importance due to its potential environmental hazards and public health risks $[6,7]$, and it is the second dangerous waste in the world that needs to be properly disposed by trained health care staff [8]. The waste generated from hospitals is now recognized as a significant problem that may have bad and dangerous effects either on the environment or on human beings through direct or indirect contact [9].

Medical waste management comprises different stages which are handling, segregation, mutilation, disinfection, storage, transportation and final disposal [9]. These are the vital steps for safe and scientific management of medical waste in any establishment. The key to minimization and effective management of medical waste is segregation and identification of the waste through sorting the waste into color coded plastic bags or containers [10].There is however no single solution to the problems of managing medical waste as different methods are used interchangeably and each practice have its own weaknesses and strengths [11]. 
In practice, medical waste are often mixed with municipal solid waste management. This is because medical waste is disposed in residential waste landfills or improper treatment facilities $[12,13]$. Currently, it seems the two areas of management are well distinguished in most countries. A number of developed countries have good frameworks through legislation and good practice guidelines which map out safe possible ways for collection, transport, storage and disposal of medical wastes [9]. Most developing countries are however lagging behind in the proper and effective management of medical waste and its practice. This improper management and practice are very hazardous to health care workers that are directly involved in dealing with medical waste as well as and members of the communities as patients or neighbouring residents. This study therefore assessed medical waste management in University College Hospital Ibadan, Nigeria.

\section{GEOGARPHICAL LOCATION OF THE STUDY AREA}

The study area University College Hospital, Ibadan is located in Ibadan North Local Government of Oyo State and on coordinate 7.402092N and 3.902007E. Other important close landmarks are: Oritamefa Baptist Church, Bovas Filling station, Kunle Ara Pharmacy, Oyo State Secretariat, Agodi Garden etc.

\section{METHODOLOGY}

The study area is the University College Hospital Ibadan. This tertiary healthcare institution is located in Ibadan, Southwestern Nigeria. The study area has the staff strength of over 3000 which comprise of 600 doctors and 1000 nurses [14]. Those who are at risk of improper medical waste management are healthcare workers, patients, waste collectors, disposal staff, and residents [15]. Based on this, health worker, waste handler, out-patients and residents were used as respondents for this research. For the sake of accuracy, the staff strength of the study area was pegged at 3000 , and $5 \%$ of the population was sampled, which amount to one hundred and fifty (150) respondents. This supports an assertion that the higher the population, the smaller the sampling ratio [16].

A multistage sampling technique was used for this study. First, a purposive sampling technique was employed in selecting the respondents. Out of the 150 respondents, $40 \%$ are health workers in which sub-profession like doctor; nurse and pathologist were identified as they are the primary generator of this waste during the discharge of their professional activities. The questionnaires were evenly distributed among them. The remaining $60 \%$ of the respondents are waste handlers, out-patients and residents; the questionnaires were also equally administered on them to ensure equal representation and to avoid bias. Details as shown in Table 1. A simple quota sampling technique was later adopted for the administration of the questionnaires until all copies of questionnaire assigned for each stakeholder were administered.

\begin{tabular}{|c|c|c|c|}
\hline S/N & Profession & No. of Questionnaire Administered & $\mathbf{0}$ \\
\hline 1. & Doctor & 20 & 13.3 \\
\hline 2. & Nurse & 20 & 13.3 \\
\hline 3. & Pathologist & 20 & 13.4 \\
\hline 4. & Waste Handler & 30 & 20.0 \\
\hline 5. & Out-Patients & 30 & 20.0 \\
\hline 6. & Residents & 30 & 20.0 \\
\hline & Total & $\mathbf{1 5 0}$ & $\mathbf{1 0 0}$ \\
\hline
\end{tabular}

Table 1:- Breakdown of Questionnaire Distribution

Data collected were analyzed using descriptive statistics done using automated means such as Statistic Package for Social Sciences (SPSS) version 20 and Microsoft Excel, 2016. Frequency and percentage were only used in the analysis of socioeconomic characteristics such as gender and age.

\section{RESULT AND DISCUSSION}

Presented in this section are the results of the findings on socioeconomic characteristics of respondents such as gender, age, educational status and their period of stay. Other information includes inventory of the medical waste management facilities, respondents' perceived medical waste generated and effect of medical waste to the environment.

\section{A. Socio-economic Characteristics of Respondents}

Out of 150 respondents sampled from the study area, $56.7 \%$ are female while $43.3 \%$ are male. Furthermore, $70.0 \%$ of these females are from waste handlers, while $58.3 \%, 21.2 \%$ and $12.9 \%$ of them are health worker, residents and patients respectively. Likewise, from the male respondents that are male, $41.7 \%$ are form health workers, while $30.0 \%, 29.2 \%$ and $18.5 \%$ are from waste handlers, patients and residents respectively. The result revealed that $28.7 \%$ of the respondents are between the ages of $31-40$ years. Those that are less than 30 years and those between 41-50 years have the same percentage of $26.7 \%$, while those between 51-60 years and above 60 years accounted for $10.0 \%$ and $7.9 \%$ respectively and these age groups were found among patients and residents. 
On educational level, $100 \%$ of the health workers have tertiary education; this level of education served as prerequisite for practice of major medical profession. While among the waste handlers, $23.3 \%$ and $10.0 \%$ of them have secondary education and primary education respectively, as ability to read and write is the prerequisite for their activities. Patients with Tertiary education claimed the largest percentage $(43.3 \%)$, followed by those with secondary and primary education with the proportion of $40.0 \%$ and $16.7 \%$ respectively. Among the residents, those with tertiary education account for $73.3 \%$ and those with secondary education represent $26.7 \%$, all of them have formal education. The questionnaire was evenly distributed among the health workers to ensure equal participation. Therefore, this result follows this pattern as nurses, doctors and pathologists have the same proportion of $22.2 \%$, while waste handlers accounts for $33.4 \%$. As at the time of conducting the interview the National Minimum wage was pegged at $\# 18,000,41.3 \%$ of the respondents earn above $\# 100,000$ and bulk of them were found among the health workers while $18.0 \%$ earn amount less than \#20,000 who are majorly found among the waste handler. Basically in
Nigeria, level of education determined the salary scale of public servant.

Medical workers and waste handlers were asked for period of employment, residents were asked period of stay, and since the patients are out-patients they were asked the period they have been coming to clinic. All these were meant to know how knowledgeable respondents are about the subject of discourse. Among the health workers, $62.3 \%$ of them have been working for period of 1-10 years, while those that had working experience of about 11-20 years and those with more than 20years account for $8.8 \%$ and $28.9 \%$ respectively. Among the patients who are out-patients, those that have been coming to clinic for less than 1year account for larger proportion as they represent $43.8 \%$, while those that have been coming between 1-2years and more than 2years represent $32.7 \%$ and $23.5 \%$.Among to the residents, those that reside in the study area for period of 1-10 years represent $64.6 \%$, while those that reside there more than 10 years and less than 1 year represent $22.7 \%$ and $12.7 \%$ respectively.

\begin{tabular}{|c|c|c|c|c|c|c|c|c|c|c|}
\hline \multirow[t]{3}{*}{ Socio-Economic } & \multicolumn{8}{|c|}{ Respondents Categories } & \multirow{2}{*}{\multicolumn{2}{|c|}{ TOTAL }} \\
\hline & \multicolumn{2}{|c|}{ Waste Handler } & \multicolumn{2}{|c|}{ Health Worker } & \multicolumn{2}{|c|}{ Out-Patients } & \multicolumn{2}{|c|}{ Residents } & & \\
\hline & $\mathbf{F}$ & $\%$ & $\mathbf{F}$ & $\%$ & $\mathbf{F}$ & $\%$ & $\mathbf{F}$ & $\%$ & $\mathbf{F}$ & $\%$ \\
\hline Male & 9 & 30.0 & 30 & 50.0 & 19 & 63.3 & 12 & 40.0 & 70 & 46.7 \\
\hline Female & 21 & 70.0 & 30 & 50.0 & 11 & 36.7 & 18 & 60.0 & 80 & 53.3 \\
\hline Sub-Total & 30 & 100.0 & 60 & 100.0 & 30 & 100.0 & 30 & 100.0 & 150 & 100.0 \\
\hline Less than 30years & 12 & 40.0 & 20 & 33.3 & 3 & 9.9 & 5 & 16.7 & 40 & 26.7 \\
\hline 31-40years & 8 & 26.7 & 30 & 50.0 & 5 & 16.7 & 0 & 0.0 & 43 & 28.7 \\
\hline 41-50years & 10 & 33.3 & 10 & 16.7 & 12 & 40.0 & 8 & 26.7 & 40 & 26.7 \\
\hline 51-60years & 0 & 0.0 & 0 & 0.0 & 5 & 16.7 & 10 & 33.3 & 15 & 10.0 \\
\hline Above 60years & 0 & 0.0 & 0 & 0.0 & 5 & 16.7 & 7 & 23.3 & 12 & 7.9 \\
\hline Sub-Total & 30 & 100.0 & 60 & 100.0 & 30 & 100.0 & 30 & 100.0 & 150 & 100.0 \\
\hline No formal education & 0 & 0.0 & 0 & 0.0 & 0 & 0.0 & 0 & 0.0 & 0 & 0.0 \\
\hline Primary & 9 & 30.0 & 0 & 0.0 & 5 & 16.7 & 0 & 0.0 & 14 & 9.4 \\
\hline Secondary & 21 & 70.0 & 0 & 0.0 & 12 & 40.0 & 8 & 26.7 & 41 & 27.3 \\
\hline Tertiary & 0 & 0.0 & 60 & 100.0 & 13 & 43.3 & 22 & 73.3 & 95 & 63.3 \\
\hline Sub-Total & 30 & 100.0 & 60 & 100.0 & 30 & 100.0 & 30 & 100.0 & 150 & 100.0 \\
\hline Less than \#20,000 & 22 & 73.3 & 0 & 0.0 & 5 & 16.7 & 0 & 0.0 & 27 & 18.0 \\
\hline$\# 20,000$ - \#50,000 & 8 & 26.7 & 0 & 0.0 & 3 & 10.0 & 5 & 16.7 & 16 & 10.7 \\
\hline$\# 50,001$ - \#100,000 & 0 & 0.0 & 18 & 30.0 & 12 & 40.0 & 15 & 50.0 & 45 & 30.0 \\
\hline Above \#100,000 & 0 & 0.0 & 42 & 70.0 & 10 & 33.3 & 10 & 33.3 & 62 & 41.3 \\
\hline Sub-Total & 30 & 100.0 & 60 & 100.0 & 30 & 100.0 & 30 & 100.0 & 150 & 100.0 \\
\hline
\end{tabular}

Table 2:- Socio-Economic Characteristics of the Respondents

\section{B. Inventory of the Medical Waste Management Facilities}

The view of health workers and waste handlers was used in this section as their perception will be more reliable than that of the patients and residents, because they are the major users of these facilities. First, were the findings on respondents' perception of medical waste management stages. Collection and segregation is the first stage of medical waste management. From the perception of the health workers and waste handlers as shown in Table 3, punctured proof container has the highest Waste Collection Index (WCI) of 4.49 with 0.54 deviations from the mean. Colour waste container was next with CWI of 4.22. Colour coded bin has the least WCI of 3.23 with deviation of -0.72 from the mean; other facilities have value that is below the mean. 


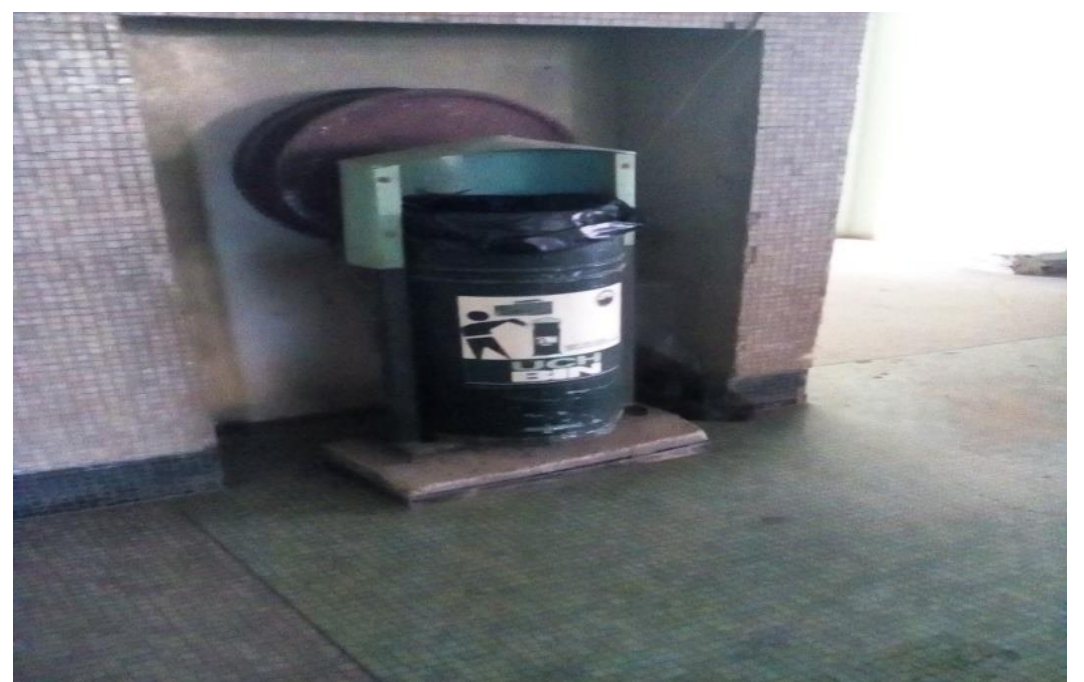

Fig 1:- Waste Bin strategically located across different session of the study area

Table 4 shows the rating of different waste storing and transportation facilities which are essential for movement of the waste from on-site to the off-site. Lidded container has the highest Waste Storing Index (WSI) of 4.56 with deviations of 0.54 from the mean. Other facilities in descending order are storage house (4.22); hand cart (3.70) and waste skip (3.50). Wheelbarrow has the least WSI of 1.11, while other facilities also have value less than the mean. Treatment and disposal is the final stage of getting rid of the medical waste.

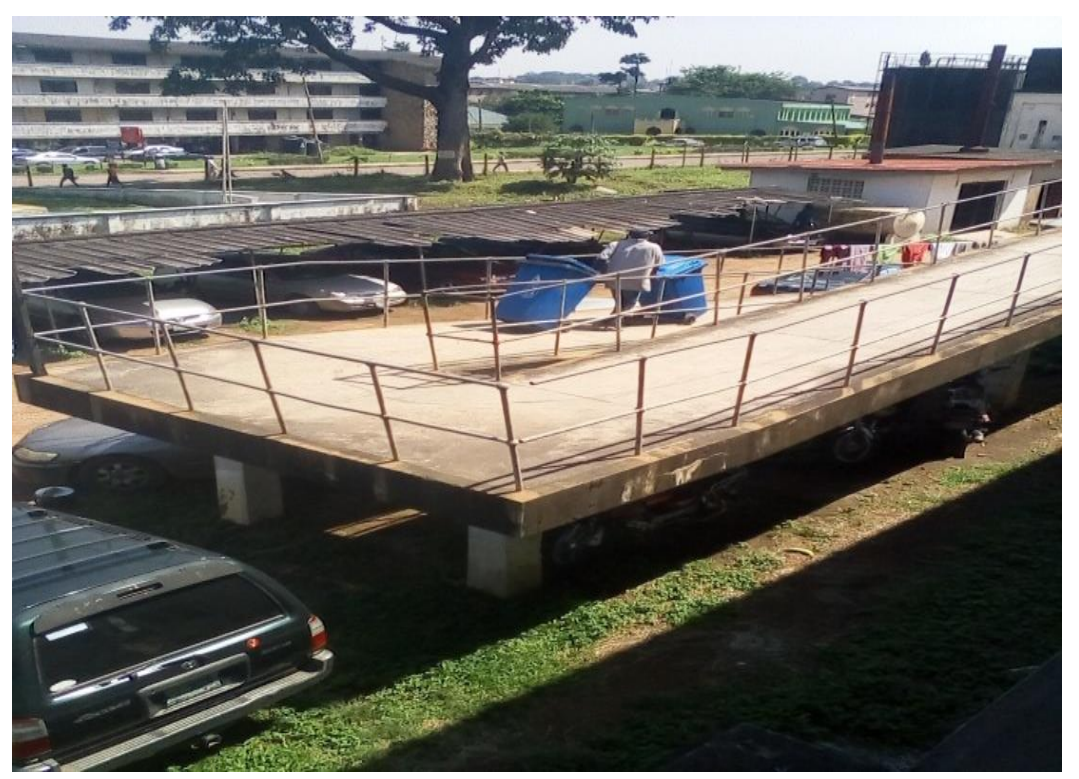

Fig 2:- Waste Handler pushing the Wheel Trolley

As revealed in Table 5, compositing and landfill have the highest and the same Waste Treatment Index (WTI) of 3.67 with deviation of 1.17 from the mean. Incineration also has positive WTI of 3.22. Other facilities have value less than the mean. From this respondents' perception, it can be deduced that compositing or landfill is the adopted means of disposing medical waste generated from the study area.

\begin{tabular}{|c|c|c|c|c|c|c|c|c|c|c|c|}
\hline \multirow[t]{2}{*}{ Facilities } & \multicolumn{5}{|c|}{ Rating } & \multirow[t]{2}{*}{$\mathbf{F}$} & \multirow[t]{2}{*}{ SWV } & \multirow[t]{2}{*}{ WCI } & \multirow[t]{2}{*}{$\mathbf{x}^{-}$} & \multirow[t]{2}{*}{$\left(\mathbf{x}-\mathrm{x}^{-}\right)$} & \multirow[t]{2}{*}{$\left(x-x^{-}\right)^{2}$} \\
\hline & 5 & 4 & 3 & 2 & 1 & & & & & & \\
\hline Puncture proof containers & 225 & 176 & 3 & 0 & 0 & 90 & 404 & 4.49 & \multirow{5}{*}{3.95} & 0.54 & 0.2916 \\
\hline Colour waste container & 250 & 80 & 30 & 20 & 0 & 90 & 380 & 4.22 & & 0.27 & 0.0729 \\
\hline Conveyor & 110 & 184 & 54 & 0 & 4 & 90 & 352 & 3.91 & & -0.04 & 0.0016 \\
\hline Plastic bag & 150 & 112 & 72 & 18 & 0 & 90 & 352 & 3.91 & & -0.04 & 0.0016 \\
\hline Colour coded bins & 55 & 92 & 132 & 0 & 12 & 90 & 291 & 3.23 & & -0.72 & 0.5184 \\
\hline Total & & & & & & & & 19.76 & & & 0.8861 \\
\hline
\end{tabular}

Table 3:- Collection and Segregation Stage Facilities 
ISSN No:-2456-2165

\begin{tabular}{|c|c|c|c|c|c|c|c|c|c|c|c|}
\hline \multirow[t]{2}{*}{ Reasons } & \multicolumn{5}{|c|}{ Rating } & \multirow[t]{2}{*}{$\mathbf{F}$} & \multirow[t]{2}{*}{ SWV } & \multirow[t]{2}{*}{ WSI } & \multirow[t]{2}{*}{$\mathbf{x}^{-}$} & \multirow[t]{2}{*}{$\left(x-x^{-}\right)$} & \multirow[t]{2}{*}{$\left(x-x^{-}\right)^{2}$} \\
\hline & 5 & 4 & 3 & 2 & 1 & & & & & & \\
\hline Lidded container & 260 & 144 & 6 & 0 & 0 & 90 & 410 & 4.56 & \multirow{8}{*}{3.00} & 1.56 & 2.4336 \\
\hline Storage house & 200 & 120 & 60 & 0 & 0 & 90 & 380 & 4.22 & & 1.22 & 1.4884 \\
\hline Hand cart & 210 & 0 & 81 & 42 & 0 & 90 & 333 & 3.70 & & 0.70 & 0.4900 \\
\hline Waste skip & 125 & 100 & 75 & 0 & 15 & 90 & 315 & 3.50 & & 0.50 & 0.2500 \\
\hline Wheeled trolley & 0 & 120 & 90 & 40 & 10 & 90 & 260 & 2.89 & & -0.11 & 0.0121 \\
\hline Wheeled bin & 0 & 40 & 90 & 40 & 30 & 90 & 200 & 2.22 & & -0.78 & 0.6084 \\
\hline Garbage truck & 0 & 0 & 54 & 78 & 33 & 90 & 165 & 1.83 & & -1.17 & 1.3689 \\
\hline Wheelbarrow & 0 & 0 & 0 & 20 & 80 & 90 & 100 & 1.11 & & -1.89 & 3.5721 \\
\hline Total & & & & & & & & 24.03 & & & 10.2235 \\
\hline
\end{tabular}

Table 4:- Storing and Transporting Stage Facilities

\begin{tabular}{|c|c|c|c|c|c|c|c|c|c|c|c|}
\hline \multirow[t]{2}{*}{ Reasons } & \multicolumn{5}{|c|}{ Rating } & \multirow[t]{2}{*}{$\mathbf{F}$} & \multirow[t]{2}{*}{ SWV } & \multirow[t]{2}{*}{ WTI } & \multirow[t]{2}{*}{$\mathbf{x}^{-}$} & \multirow[t]{2}{*}{$\left(x-x^{-1}\right)$} & \multirow[t]{2}{*}{$\left(x-x^{-1}\right)^{2}$} \\
\hline & 5 & 4 & 3 & 2 & 1 & & & & & & \\
\hline Compositing & 125 & 100 & 75 & 30 & 0 & 90 & 330 & 3.67 & \multirow{7}{*}{2.50} & 1.17 & 1.3689 \\
\hline Landfill & 150 & 80 & 60 & 40 & 0 & 90 & 330 & 3.67 & & 1.17 & 1.3689 \\
\hline Incineration & 100 & 80 & 60 & 40 & 10 & 90 & 290 & 3.22 & & 0.72 & 0.5184 \\
\hline Steam disinfection & 0 & 60 & 45 & 60 & 30 & 90 & 195 & 2.17 & & -0.33 & 0.1089 \\
\hline Gas disinfection & 0 & 0 & 90 & 60 & 30 & 90 & 180 & 2.00 & & 0.50 & 0.2500 \\
\hline Chemical disinfection & 0 & 0 & 0 & 80 & 50 & 90 & 130 & 1.44 & & -1.06 & 1.1236 \\
\hline Recycling & 25 & 0 & 0 & 20 & 75 & 90 & 120 & 1.33 & & -1.17 & 1.3689 \\
\hline Total & & & & & & & & 17.50 & & & 6.1076 \\
\hline
\end{tabular}

Table 5:- Treatment and Disposal Stage Facilities

Considering waste segregation type, from the view of health workers and waste handlers sampled, which amount to 90respondents out of 150 sampled size, $88.9 \%$ of them revealed that there is a means of segregating medical waste which was done at the point of use, $44.4 \%$ of them affirmed that leak proof container is the major segregation facilities in the study area. Likewise, it was attested to that coloured coded bin $(22.2 \%)$ and coloured waste container $(11.1 \%)$ are the major segregation facilities, while those that revealed that nylon bag and plastic bag is the segregation facilities account for $13.3 \%$ and $9.0 \%$ respectively. Likewise, $73.4 \%$ of the respondents affirmed that there is training for the waste handlers, as this is needful as they need to have up-to-date full knowledge of the risk involved in improper handling of the medical waste.

On the period of storing medical waste, health institution ought to keep record of waste generated, as this will help them to keep track record of waste management [17], $62.3 \%$ revealed they are aware that the record keeping are being done, while $37.7 \%$ revealed that they are not aware of the process. Also, $44.4 \%$ of them revealed that medical waste is being stored for a period of 2-3 months; $42.2 \%$ affirmed that it was stored for a period of 4-5 months, while $13.4 \%$ said period of storage is less than a month. As revealed by $68.0 \%$ of the respondents, waste collector agents are government owned, with assumption that necessary principles will be obeyed. Not like private company that does it for gain purpose as agreed by $32.0 \%$ of the respondents.

An assessment was also done on health workers' perceived condition of facilities used for protection from possible hazard of medical waste. And as shown in Table 6, Gloves that are in good condition top the facility used by waste handlers with Facility Condition Index (FCI) of 4.40 with deviation of 2.09 from the mean. Other facilities in descending order are safety shoes (3.67), googles (2.72) and apron (2.67).Head cap has the least FCI with value of 1.00 with deviation of -1.31 from the mean.

The waste storage facility in the study area was analyzed (table 7), using international indicators for citing a waste storage plant. Good accessibility has the highest Storage Factor Index (SFI) of 4.53, other indicators are far from the hospital room (4.46), hygienic and sanitation (3.56), exclusively located (2.98) and adequate security (2.64). Only close to the door is the only indicator that has a negative deviation of -0.85 from the mean and least WSI of 1.62 . 


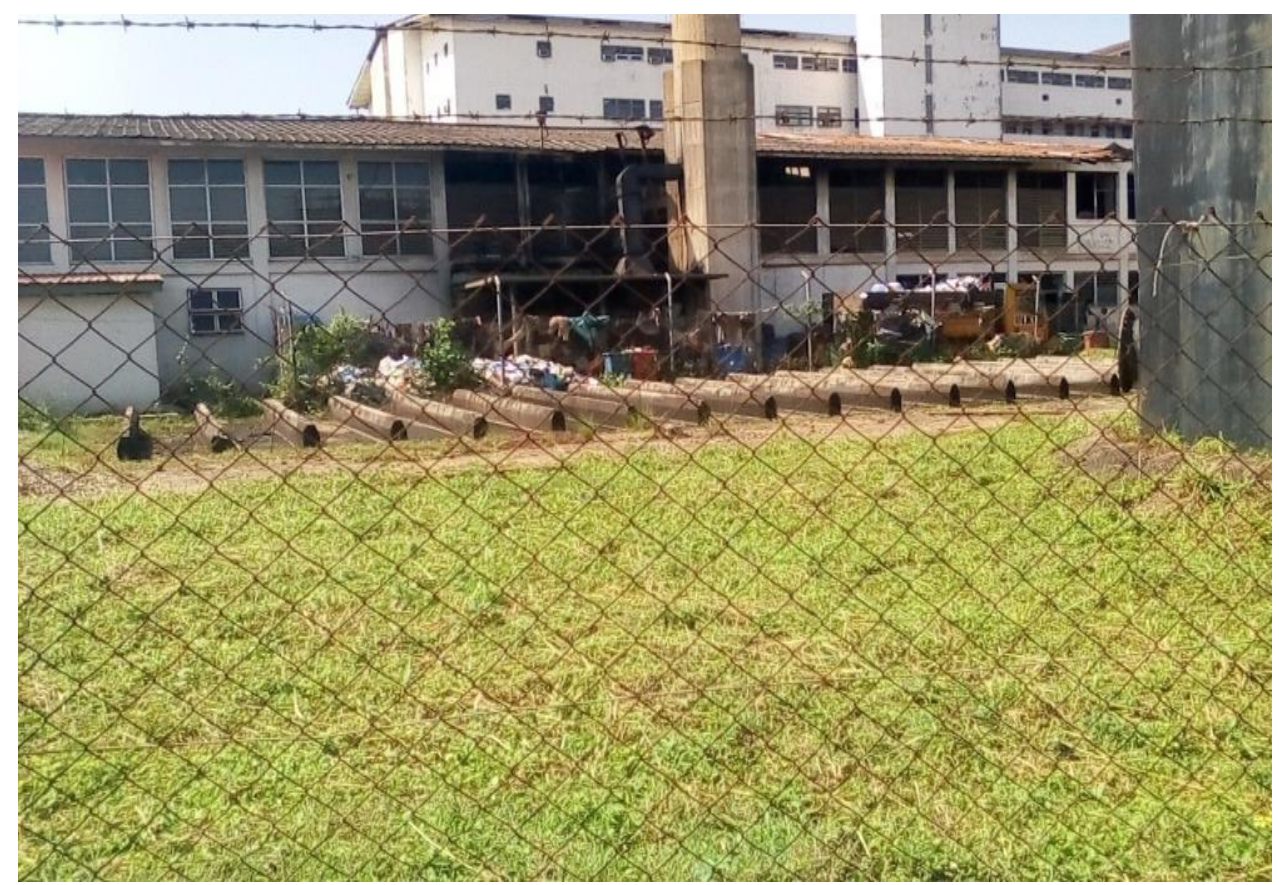

Fig 3:- A Placed assumed to be Waste Storage Plant with Garbage Truck in Front

\begin{tabular}{|c|c|c|c|c|c|c|c|c|c|c|c|}
\hline \multirow[t]{2}{*}{ Facilities for Handler } & \multicolumn{5}{|c|}{ Rating } & \multirow[t]{2}{*}{$\mathbf{F}$} & \multirow[t]{2}{*}{ SWV } & \multirow[t]{2}{*}{ FCI } & \multirow[t]{2}{*}{$\mathbf{x}^{-}$} & \multirow[t]{2}{*}{$\left(\mathbf{x}-\mathbf{x}^{-}\right)$} & \multirow[t]{2}{*}{$\left(x-x^{-}\right)^{2}$} \\
\hline & 5 & 4 & 3 & 2 & 1 & & & & & & \\
\hline Gloves & 275 & 64 & 57 & 0 & 0 & 90 & 396 & 4.40 & \multirow{6}{*}{2.31} & 2.09 & 4.3681 \\
\hline Safety shoes & 125 & 100 & 75 & 30 & 0 & 90 & 330 & 3.67 & & 1.36 & 1.8496 \\
\hline Googles & 0 & 48 & 162 & 0 & 35 & 90 & 245 & 2.72 & & 0.41 & 0.1681 \\
\hline Apron & 75 & 48 & 54 & 36 & 27 & 90 & 240 & 2.67 & & 0.36 & 0.1296 \\
\hline Mask & 0 & 0 & 90 & 60 & 40 & 90 & 190 & 2.11 & & -0.20 & 0.0400 \\
\hline Head cap & 0 & 0 & 0 & 0 & 90 & 90 & 90 & 1.00 & & -1.31 & 1.7161 \\
\hline Total & & & & & & & & 13.90 & & & 8.2715 \\
\hline
\end{tabular}

Table 6:- Perceived Condition of Facilities for Waste Handler

\begin{tabular}{|c|c|c|c|c|c|c|c|c|c|c|c|}
\hline \multirow[t]{2}{*}{ Criteria for Waste Storage Plant } & \multicolumn{5}{|c|}{ Rating } & \multirow[t]{2}{*}{$\mathbf{F}$} & \multirow[t]{2}{*}{ SWV } & \multirow[t]{2}{*}{ SFI } & \multirow[t]{2}{*}{$\mathbf{x}^{-}$} & \multirow[t]{2}{*}{$\left(\mathbf{x}-\mathbf{x}^{-}\right)$} & \multirow[t]{2}{*}{$\left(x-x^{-}\right)^{2}$} \\
\hline & 5 & 4 & 3 & 2 & 1 & & & & & & \\
\hline Good accessibility & 260 & 136 & 12 & 0 & 0 & 90 & 408 & 4.53 & \multirow{6}{*}{2.47} & 2.06 & 4.2436 \\
\hline Far from the hospital room & 205 & 196 & 0 & 0 & 0 & 90 & 401 & 4.46 & & 1.99 & 3.9601 \\
\hline Hygienic and sanitation & 125 & 40 & 135 & 20 & 0 & 90 & 320 & 3.56 & & 1.09 & 1.1881 \\
\hline Exclusively located & 0 & 192 & 36 & 40 & 0 & 90 & 268 & 2.98 & & 0.51 & 0.2601 \\
\hline Adequate security & 25 & 32 & 102 & 72 & 7 & 90 & 238 & 2.64 & & 0.17 & 0.0289 \\
\hline Close to site door & 0 & 0 & 54 & 40 & 52 & 90 & 146 & 1.62 & & -0.85 & 0.7225 \\
\hline Total & & & & & & & & 19.79 & & & 10.4033 \\
\hline
\end{tabular}

Table 7:- Perceived Condition of Waste Storage Facilities

\section{Respondents' Perceived Medical Waste Generated}

Perception of all the respondents was used in this section. Medical waste was categorized into eight [17], this categorization was also employed for this study. From the perception of the respondents, Infectious waste is the most generated medical waste in the study area with the highest Medical Waste Index (MWI) of 4.46 with deviation of 1.90 from the mean, sharps are the next waste with MWI of 4.21 with deviation of 1.65 from the mean. Other wastes with positive value from the mean are pathological and general waste with MWI of 2.61 and 2.57 respectively. Wastes like radioactive, pharmaceutical, pressurized container and chemical have the lowest MWI's of 2.20, 1.78, 1.47 and 1.19 respectively. This indicates low generation of these wastes at the study area. 
ISSN No:-2456-2165

\begin{tabular}{|c|c|c|c|c|c|c|}
\hline \multirow{2}{*}{$\begin{array}{c}\text { Categories of Medical } \\
\text { Waste }\end{array}$} & \multicolumn{3}{|c|}{ MWI for the Study Area } & \multirow[t]{2}{*}{ MWI } & \multirow[t]{2}{*}{ MWI - *MWI } & \multirow[t]{2}{*}{$(M W I \text { - *MWI })^{2}$} \\
\hline & Health Worker & Patients & Residents & & & \\
\hline Infectious waste & 4.37 & 4.33 & 4.67 & 4.46 & 1.90 & 3.61 \\
\hline Sharps & 4.00 & 4.33 & 4.30 & 4.21 & 1.65 & 2.72 \\
\hline Pathological & 2.00 & 3.83 & 2.00 & 2.61 & 0.05 & 0.00 \\
\hline General waste & 2.56 & 2.73 & 2.43 & 2.57 & 0.01 & 0.00 \\
\hline Radioactive & 3.00 & 1.60 & 2.60 & 2.20 & -0.36 & 0.13 \\
\hline Pharmaceutical & 1.67 & 2.00 & 1.67 & 1.78 & -0.78 & 0.61 \\
\hline Pressurized container & 1.56 & 1.33 & 1.53 & 1.47 & -1.09 & 1.19 \\
\hline Chemical & 1.56 & 1.00 & 1.00 & 1.19 & -1.37 & 1.88 \\
\hline Total & 20.72 & 21.15 & 20.20 & 20.49 & & \\
\hline *MWI & 2.59 & 2.64 & 2.53 & 2.56 & & \\
\hline
\end{tabular}

Table 8:- Respondents Perceived Medical Waste Generated

\section{Effect of Medical Waste to the Environment}

The mean of Waste Effect Index (WEI) value of the study area is 2.79. Medical waste has different effects on the populace. Major effect of the medical waste in the study area is offensive odour with highest WEI of 3.77 with deviation of 0.98 from the mean. This is followed by other effects like exposure to viral and bacterial infection (3.55), airborne disease (3.03). Other two effects have value less the mean of the study area; they are contaminated groundwater (2.07) and radioactive disease (1.53).

\begin{tabular}{|c|c|c|c|c|c|c|}
\hline \multirow[t]{2}{*}{ Effects } & \multicolumn{3}{|c|}{ WEI for the Study Area } & \multirow[t]{2}{*}{ WEI } & \multirow[t]{2}{*}{ WEI - *WEI } & \multirow[t]{2}{*}{$(\mathrm{WEI}-* \mathbf{W E I})^{2}$} \\
\hline & Health Worker & Patients & Residents & & & \\
\hline Offensive odour & 3.94 & 3.53 & 3.83 & 3.77 & 0.98 & 0.96 \\
\hline Exposure to viral and bacterial infection & 3.74 & 3.23 & 3.67 & 3.55 & 0.76 & 0.58 \\
\hline Airborne diseases & 2.97 & 3.40 & 2.73 & 3.03 & 0.24 & 0.06 \\
\hline Contaminated groundwater & 2.07 & 1.80 & 2.33 & 2.07 & -0.72 & 0.51 \\
\hline Radioactive diseases & 1.58 & 1.67 & 1.33 & 1.53 & -1.26 & 1.59 \\
\hline Total & 14.30 & 13.63 & 13.89 & 13.95 & & \\
\hline *WEI & 2.86 & 2.73 & 2.78 & 2.79 & & \\
\hline
\end{tabular}

Table 9:- Respondents Perceived Effect of Medical Waste

\section{E. Preventive Measure for Proper Medical Waste Management}

From table 9, major preventive measures as perceived by the respondents are enforcement of regulation with Waste Preventive Index (WPI) of 4.16 with deviation of 0.66 from the mean. Enforcing rules will serve as check and balance to the stakeholders to strictly adhere to standard medical waste management practice. Other preventive measures as perceived by the respondents are proper transportation from on-site to off-site (4.09) and identify each hazardous waste (3.75) with deviation of 0.59 and 0.25 from the mean respectively. Count the total weight of hazardous materials and recycling have the least WPI's of 3.21 and 2.30 respectively. This shows that respondents do not consider these measures as the best preventive measures from effects of the medical waste.

\begin{tabular}{|c|c|c|c|c|c|c|}
\hline \multirow[t]{2}{*}{ Preventive Measures } & \multicolumn{3}{|c|}{ WPI for the Study Area } & \multirow[t]{2}{*}{ WPI } & \multirow{2}{*}{$\begin{array}{l}\text { WPI - } \\
* \text { WPI }\end{array}$} & \multirow{2}{*}{$\begin{array}{l}\text { (WPI - } \\
* \text { WPI })^{2}\end{array}$} \\
\hline & Health Worker & Patients & Residents & & & \\
\hline Enforcement of regulation & 3.67 & 4.40 & 4.40 & 4.16 & 0.66 & 0.44 \\
\hline $\begin{array}{l}\text { Proper transportation from on-site to off- } \\
\text { site }\end{array}$ & 3.70 & 4.37 & 4.20 & 4.09 & 0.59 & 0.35 \\
\hline Identify each hazardous waste & 3.79 & 3.90 & 3.57 & 3.75 & 0.25 & 0.06 \\
\hline $\begin{array}{l}\text { Count the total weight of hazardous } \\
\text { materials }\end{array}$ & 3.06 & 3.23 & 3.33 & 3.21 & -0.29 & 0.08 \\
\hline Recycling & 3.00 & 1.67 & 2.23 & 2.30 & -1.20 & 1.44 \\
\hline Total & 17.22 & $\mathbf{1 7 . 5 7}$ & 17.73 & $\mathbf{1 7 . 5 1}$ & & \\
\hline * WPI & 3.44 & 3.51 & 3.55 & $\mathbf{3 . 5 0}$ & & \\
\hline
\end{tabular}

Table 10:- Respondents' Perceived Preventive Measure for Proper Medical Waste Management 


\section{F. Health Workers Satisfactory}

Special package for workers enhance their enthusiasm for their job. Health workers' perception was used to measure best option that can really work. In their view, workers' welfare has the highest Health Workers Satisfactory Index (HSI) of 3.57 with deviation of 0.37 from the mean; likewise provision of equipment's' has WSI of 3.50. Other HSIs has negative deviation from the mean, like training for the handlers (3.19), government intervention (3.18), adequate funding (3.10), while adherence to medical waste management procedure has the least WSI of 2.63 with deviation of -0.57 from the mean. This does not imply that this option is not the best, but it may not work for health workers in the study area.

\begin{tabular}{|c|c|c|c|c|c|c|c|c|c|c|c|}
\hline \multirow[t]{2}{*}{ Criteria for Waste Storage Plant } & \multicolumn{5}{|c|}{ Rating } & \multirow[t]{2}{*}{$\mathbf{F}$} & \multirow[t]{2}{*}{ SWV } & \multirow[t]{2}{*}{ HIS } & \multirow[t]{2}{*}{$\mathbf{x}^{-}$} & \multirow[t]{2}{*}{$\left(\mathbf{x}-\mathbf{x}^{-}\right)$} & \multirow[t]{2}{*}{$\left(x-x^{-}\right)^{2}$} \\
\hline & 5 & 4 & 3 & 2 & $\mathbf{1}$ & & & & & & \\
\hline Workers welfare & 125 & 128 & 36 & 22 & 10 & 90 & 321 & 3.57 & \multirow{6}{*}{3.20} & 0.37 & 0.1369 \\
\hline Provision of equipment & 125 & 60 & 105 & 20 & 5 & 90 & 315 & 3.50 & & 0.30 & 0.0900 \\
\hline Training for the handlers & 130 & 64 & 36 & 42 & 15 & 90 & 287 & 3.19 & & -0.01 & 0.0000 \\
\hline Government intervention & 115 & 72 & 48 & 36 & 15 & 90 & 286 & 3.18 & & -0.02 & 0.0000 \\
\hline Adequate funding & 80 & 76 & 81 & 28 & 14 & 90 & 279 & 3.10 & & -0.10 & 0.0100 \\
\hline $\begin{array}{l}\text { Adhere to medical waste management } \\
\text { procedure }\end{array}$ & 45 & 52 & 102 & 8 & 30 & 90 & 237 & 2.63 & & -0.57 & 0.3249 \\
\hline Total & & & & & & & & 19.17 & & & 0.5618 \\
\hline
\end{tabular}

Table 11:- Perceived Health Workers Satisfactory

\section{RECOMMENDATIONS AND CONCLUSION}

This research assessed waste management practice in University College Hospital, Ibadan, Nigeria. It was observed that proper management of this special waste should be responsibility of government and private agencies. This study found out that there is training for the waste handlers as revealed by majority of the health workers and the wastes are being stored for period of 23 months.It was observed the glove, that is in good condition is the major facility used by the handlers and infectious waste is the major generated waste in the study area. Also, waste storage plant in the study area has a good accessibility which is part of international indicator. Major effect of the waste to the environment is offensive odour and this and other effects can be regulated by enforcing management practice laws. And workers' welfare is paramount for them to discharge their duties optimally.

It is concluded that all hands must be on decks by all stakeholders involved in proper medical waste management so that hospital which ought to be saving lives will not be a source of death trap to the populace. For proper medical waste management practice, the following recommendations are made:

1. There should be an incentive package for health workers as this will increase their enthusiasm towards their jobs.

2. Adequate fund should be provided to carry out this proper management of medical waste from on-site to offsite disposal.

3. There should be time-to-time training for waste handlers to keep them abreast of the recent risk involved or update about medical waste.

4. Waste management policy should be re-assessed and reviewed where necessary so as to keep it up-to date.
5. There should be proper monitoring by government agency by enforcing and regulating the activities of hospital on proper waste management practice.

6. Sustainable waste management practice should be adopted like using of modern technology equipment for waste transfer.

\section{REFERENCES}

[1]. Federal Ministry of Health, Mission statement of health institution. Available at: www.health.gov.ng/index.php/department/hospitalservices. Accessed September 5, 2018

[2]. P.Bloland, P. Simone, B. Burkholder, L. Slutsker and K.M. De Cock, "The role of public health institutions in global health system strengthening efforts: the US CDC's perspective". PloS Medicine, 9(4), 2012. e1001199. doi:10/1371/journal/pmed.1001199

[3]. B. K. Lee, M. Ellenbecker and R. Moure-Ersaso, "Alternatives for treatment and disposal cost reduction of regulated medical wastes". Waste Management, 24, 143-151, 2004

[4]. S.V. Manyele, "Medical waste management in Tanzania: current situation and the way forward". African Journal of Environmental Management, 8(1), 74-99, 2004.

[5]. A. Z. Alagoz and G. Kocasoy, "Improvement and modification of the routing system for the health-care waste collection and transportation in Istanbul." Waste Management, 28, 1461-1471, 2008.

[6]. M. H. Dehghani, K. Azam, F. Changani and E. Dehghani, "Assessment of medical waste management in Educational Hospital Tehran University Medical Sciences." Iran. Journal of Environmental Health Science and Engineering, 5(2), 131-136 E, 2008. 
[7]. V. Ferreira and M.R. Teixeira, "Assessing the medical waste management practices and associated risk perceptions in Algarve Hospitals, Portugal." International Solid Waste Association. Available at: www.iswa.org. Accessed September 10, 2018

[8]. R. Kumar, Z. Gorar, J. Ahmed, Z. Ali, A. Chandio, M. Magan, N. Ahmed, B. Shaikh, and R. Somrongthong, "Assessment of health care waste management practices and knowledge among health care workers working at tertiary care setting of Pakistan." Journal of Health Research, 27(4), 233-236, 2013. https://www.tcithaijo.org/index.php/jhealthres/article/view/88678.

[9]. M. Abdullah and S.H. Al-Mukhtar, "Assessment of medical waste management in teaching hospitals in Mosul City: a descriptive study." Mosul Nursing Journal, 1(1), 1-8, 2013.

[10]. L. Rao, W. Ranyal, L. Bhatia and L. Sharma, "Biomedical waste management: an infrastructural survey of hospitals." Medical Journal Armed Forces India, 60, 379- 382 L, 2004.

[11]. F. Nemathaga, S. Maringa and L. Chimuka, "Hospital solid waste management practices in Limpopo Province, South Africa: a case study of two hospitals." Waste Management, 28, 1236-1245, 2008.

[12]. U.S. Environmental Protection Agency, "Characterization of municipal solid waste in the United States. Washington, DC: Solid Waste and Emergency Response.”, 1990.

[13]. J. Singh, R. Laurenti, R. Sinha and B. Frostell, "Progress and challenges to the global waste management system." Waste Management \& Research, 32(9) 800 -812, 2014.

[14]. A.O. Iyun, S.A. Ademola, A. Michael, O. Olawoye and O. Oluwatosin, "Perception of healthcare professionals in University College Hospital, Ibadan towards wound care." Nigerian Journal of Plastic Surgery, 12(2), 47-49, 2016.

[15]. I. Airlina, "Medical Waste Disposal - The Definitive Guide." Biomedical Waste Solutions. www.biomedicalwastesolutions.com/medical-wastedisposal/ accessed 10/07/2018

[16]. W.L. Neuman, "Social research method: qualitative and quantitative approaches." 3rd Edition. Boston: Allyn and Bacon, 1997.

[17]. World Health Organization, "Unsafe injection practices and transmission of blood borne pathogens." Bulletin World Health Organisation, 77, 787-819, 1997. 